\title{
Outlook of the Solar Photovoltaic Energy in Spain
}

\author{
Manuel Vazquez \\ University of Vigo \\ E.T.S.Ingenieros Industriales \\ Lagoas - Marcosende, 36202 Vigo (Spain) \\ phone:+34 986812179, fax:+34 986812201, e-mail: mvazquez@uvigo.es
}

\begin{abstract}
In this paper, the state of development and outlook of the solar photovoltaic energy in Spain are analyzed in the framework of the Action Plan included in the 1997 European Commission White Paper of the Energy. The reviewed topics are the installed PV power, legislation and incentives, market situation and $\mathrm{I}+\mathrm{D}+\mathrm{I}$ activities. It is showed that the objectives for year 2010 are established as well as the legislative base. There are government financial aids but they have showed scarce to fulfil the objectives. In Spain there is an important PV industry at a world level as well as plenty of suppliers and installers.
\end{abstract}

\section{Key words}

Solar Energy, Photovoltaic, Spain, Development, White Paper

\section{Introduction}

The state of exploitation of the renewable energies in Europe as well as the strategy and action plan to increase its contribution to the energy balance of the EU, are summarized in the White Paper of the Energy [1], approved by the European Commission in November 1997, and assumed by Spain as a member state of the European Union. The global objective of the White Paper is to increase the $6 \%$ of contribution of Renewable Energies in the gross domestic energy consumption in that year above a $12 \%$ in 2010 . As far as the electricity production, the objective is to happen of a percentage of contribution of $14 \%$ in that year to $22 \%$ in the 2010 . In the contribution considered by sectors, the objective anticipated for the photovoltaic solar energy is to pass from about $70 \mathrm{MWp}$ of power installed in that year to 3 GWp until year 2010 .

Although the number of $3 \mathrm{GWp}$ of installed PV power in the European Union until year 2010 is in comparison with other energies, even renewable, low in absolute terms (for example, the forecasts for the Wind
Energy are of $36 \mathrm{GW}$ for 2010), nevertheless, this technology will be the one of greater growth maintained annual (at the moment of $30 \%$ ) and with greater possibilities of continuing being developed after 2010 . The E.U. investments to reach that power are considered to be 9 billion euro $\left(9 \times 10^{9} €\right)$ with an annual volume of sales in the 2010 of 1.5 billion euro $\left(1,5 \times 10^{9} €\right)$ and the creation of about 100,000 new jobs [2].

According to the White Paper, each State Member must define its own strategy and propose within it its contribution to the global objective, indicate how it hopes to be the contribution of the diverse technologies and summarize the measures that it proposes to introduce to obtain the increase of the utilization.

In the following sections the situation, strategies and prospects of the Solar Photovoltaic Energy in Spain will be analyzed.

\section{Power Installed}

The yearly average growth rate of the photovoltaic power installed in Spain in the last years has been of the order of $30 \%$ as it is showed in Figure 1. This rate of growth is similar to the average rate in Europe and it has supposed that in 2001 around $3.5 \mathrm{MWp}$ have entered in operation. The estimates for 2002 are that the $20 \mathrm{MWp}$ of installed capacity have been surpassed. These numbers cause that Spain ranks in fifth position of E.U. countries with respect to the PV power installed, see Figure 2. These numbers, although important, are not sufficient to reach the objectives fixed by Spain for year 2010.

\section{Legislation and Incentives}

The development of the photovoltaic energy in Spain has been possible thanks to the aids given by the European Commission and National and Regional Governments, and to the favourable legislation on renewable energies. In 1980 the Law of Conservation of 
Source: IDAE (2002 estimated)

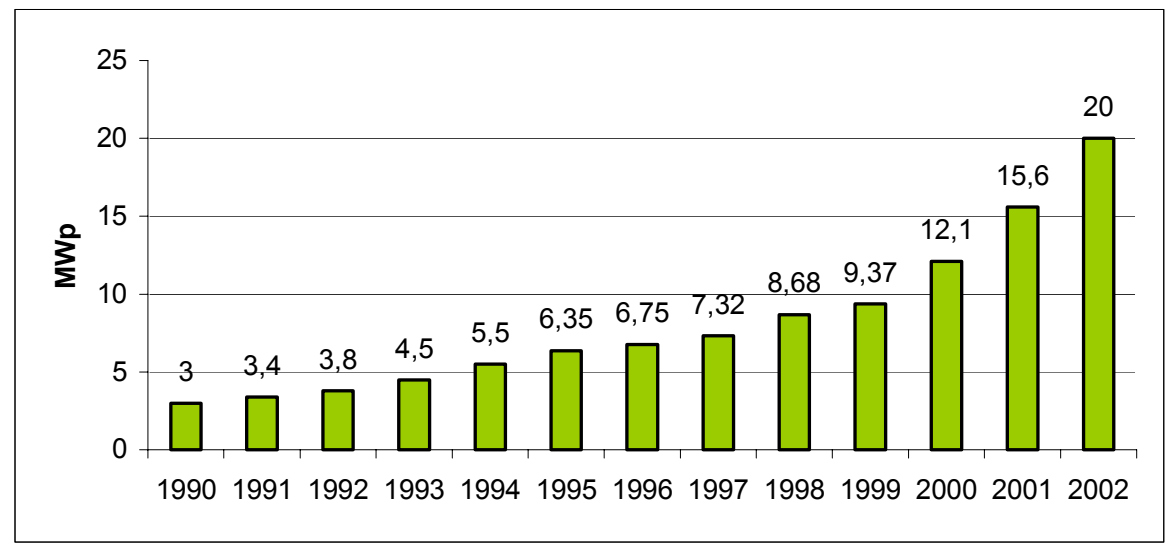

Figure 1. Installed PV power in Spain (MWp)

Source: Le Barometre des energies renouvelables 2001. Observ'ER

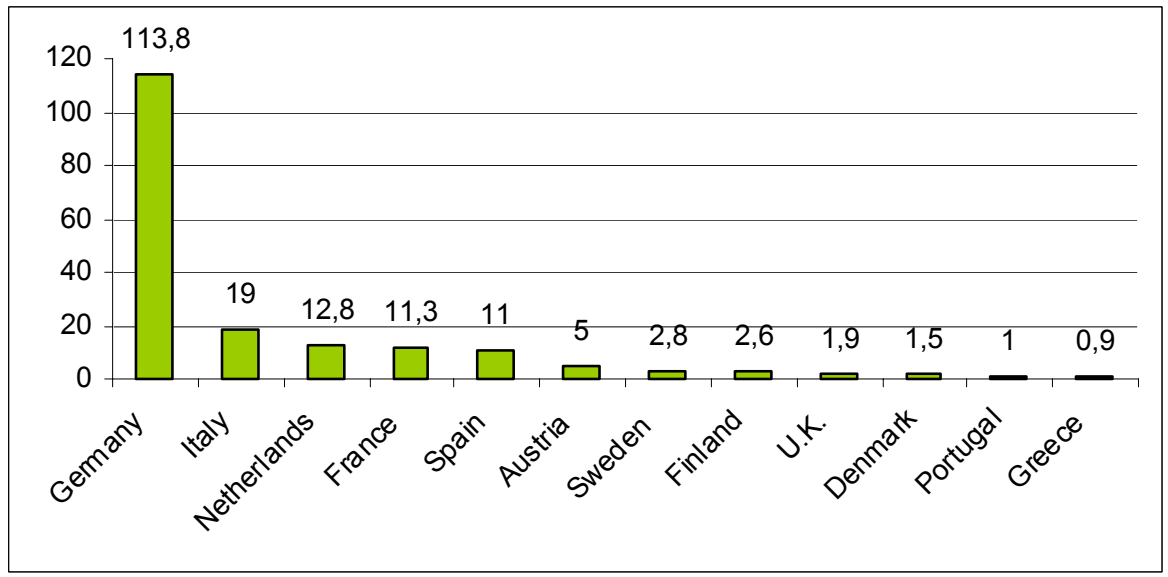

Figure 2. PV power installed in the European Union year 2001 (MWp)

the Energy (Ley de Conservación de la Energía) was approved with the objective to harness the power efficiency and the development of the local energies between which the renewable energies were included. The National Power Plan 1991-2000 ( Plan Energético Nacional 1991-2000) was approved in 1990 and to it was assigned the Plan of Power Saving and Efficiency (Plan de Ahorro y Eficiencia Energética - PAEE) that allowed to finance renewable power plants. In 1994 the Law of Arrangement of the Electrical System (Ley de Ordenación del Sistema Eléctrico) was also approved.

In 1997 the Law of the Electrical Sector (Ley del Sector Eléctrico) was approved that establishes the principles of the free competition and makes them compatible with a special regime of production of electrical energy. In this law the objective for 2010 to reach a cover of the power primary consumption of $12 \%$ with renewable energies is advanced. On December 23, 1998 the Real Decree 2818 (Real Decreto 2818) was approved that developed the Law of the Electrical Sector. This R.D. regulates the administrative, technical and economic aspects of the electricity producers with a power lower than $50 \mathrm{MW}$. In relation to the PV electricity, a premium of $60 \mathrm{Pts} / \mathrm{kWh}(\sim 36 \mathrm{c} €)$ for facilities of less than $5 \mathrm{~kW}$ (for the period of time in that the installed national power of this type of facilities does not surpass the $50 \mathrm{MW})$ and of $30 \mathrm{Pts} / \mathrm{kWh}(\sim 18 \mathrm{c} €)$ for the rest, are established.

The Real Decree 1663/2000 (Real Decreto 1663/2000) makes specific the administrative and technical conditions for the connection to the low tension grid of photovoltaic facilities of less than $100 \mathrm{kVA}$ and the Resolution of the Directorate General for Energy Policy and Mines of May 31, 2001 establishes contract model and type of invoices for photovoltaic solar facilities connected to the grid.

The Renewable Energy Promotion Plan ( Plan de Fomento de las Energías Renovables) for the period 2000-2010 was approved on December 30, 1999 [3]. The main objective of the Plan is to pass from the $6 \%$ of consumption of primary renewable energy in 1998 to 12 $\%$ in the 2010 (in agreement with the Law of the Electrical Sector and an objective similar to that fixed for all the European Union). With respect to the Photovoltaic Energy, the Plan estimates the potential market for 2010 in $2300 \mathrm{MWp}$ but the proposed objectives are: $20 \mathrm{MWp}$ in isolated installations with investments of 120 million euros; $65 \mathrm{MWp}$ in grid-connected facilities of power greater than $5 \mathrm{~kW}$ and with an investment of 194 million 
euros; and $50 \mathrm{MW}$ in grid-connected facilities of power smaller than $5 \mathrm{~kW}$ and with an investment of 150 million euros. That is to say, altogether to the photovoltaic sector 135 installed MWp are assigned for 2010 with a total investment of 464 million euros.

This Plan has been accompanied by programs of aid to the photovoltaic solar energy. Both Resolutions of the Institute for the Diversification and Saving of Energy (Instituto para la Diversificación y Ahorro Energético IDAE) during the years 2001 and 2002 have allowed to certify a great number of collaborating companies for the accomplishment of photovoltaic facilities. The IDAE has also destined 6 million euros in 2001 and 10.8 million euros in 2002 to aids for photovoltaic projects of less than $100 \mathrm{kVA}$. For projects of power superior to 100 $\mathrm{kVA}$, the same IDAE along with the Institute of Official Credit (ICO) discounts 5 points on the type of interest until $70 \%$ of the cost of the project.

In spite of all these aids and incentives, the present rate of growth of the photovoltaic sector in Spain is insufficient to reach the $135 \mathrm{MW}$ in 2010. The aids have shown to be insufficient because the total power of the requests of aids comes duplicating to the power annually that can be financed with the assigned bottoms. In order to reach the numbers it would be necessary to install 61
MW before $2006-15 \%$ in isolated facilities and $85 \%$ in grid-connected facilities. To reach this goal, it would be necessary to start up $9 \mathrm{MW}$ annually and to triple the aids that are granting [4].

\section{Photovoltaic Market}

The PV market is being developed of form maintained and shows a maturity as other established technologies although of unequal form according to the regions of Spain, being Andalusia the most outstanding region. The number of installers with certificate of the IDAE approaches 200 and more and more are specialized and professional. The number of jobs in the sector is growing exponentially.

The production of PV cells and modules in Spain in 2001 has represented $9 \%$ of the world-wide production and $37 \%$ of the European production. This production is distributed basically in three manufacturers: Isofotón, BP Solar and Atersa. The production has a growth rate of 40 $\%$, exporting $85 \%$ of it. As an example we see in Figure 3 the evolution of the volume of sales of Isofotón, and in Figure 4 the exponential growth of the number of jobs, as a consequence.

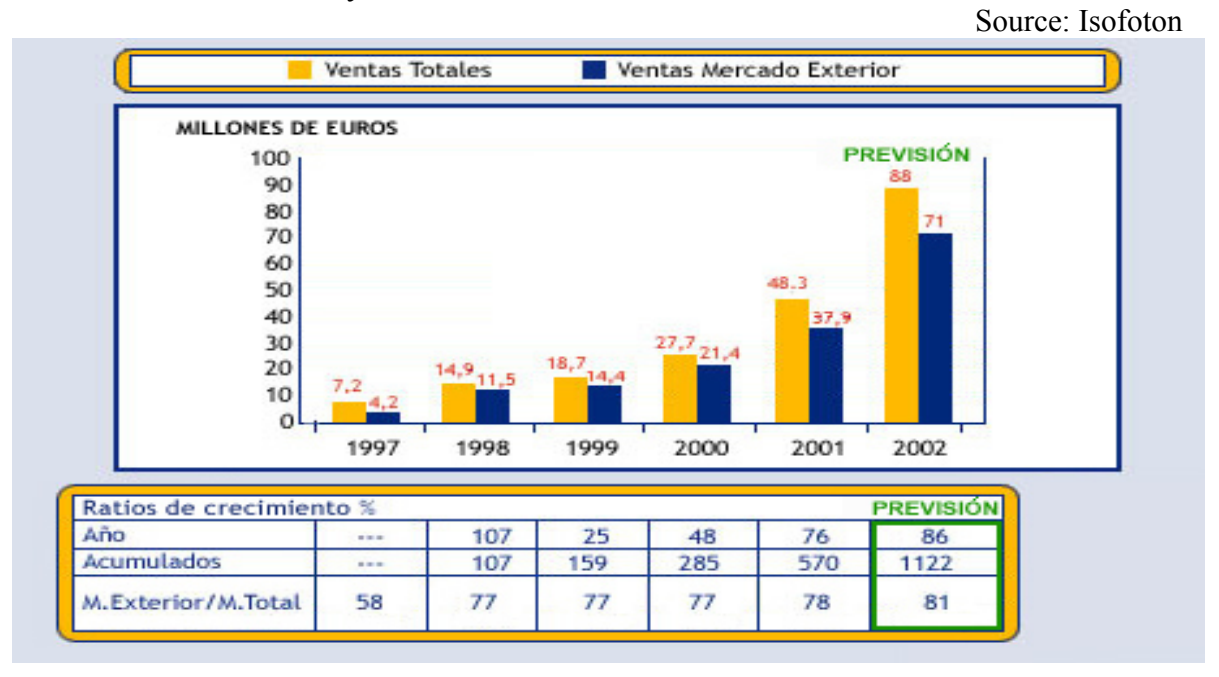

Figure 3. Evolution of Isofotón Sales

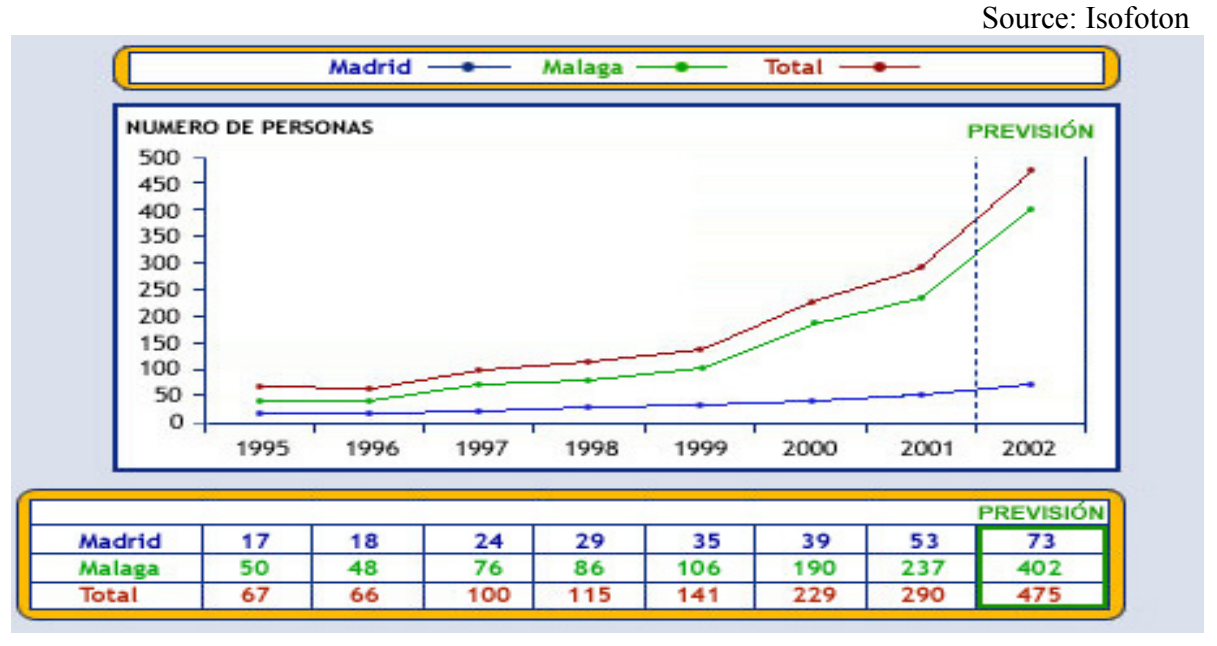

Figure 4. Evolution of Isofotón Staff 
Isofotón has duplicated its volume of production recently. The same happens to BP Solar, whose volume of sales in 2002 went up to around the 100 million euros of which $85 \%$ went to the export. BP Solar had in 2002 a staff of 450 people. BP Solar has finished in 2002 a new factory in Madrid that is going to have a production of 60 MW/year, with the creation of 300 new jobs in the initial phase. For the year 2005 the factory is expected to produce $100 \mathrm{MW} / \mathrm{year}$ and will have a staff of 1000 people. Atersa follows by the same way.

Other more recent manufacturers of modules are TFM that makes structural modules on order and Siliken. This last maker expects to reach a volume of production of 1.5 MW during the present exercise.

In Spain also diverse manufacturers of regulators and inverters for photovoltaic exist like Enertron, Trama Tecnoambiental, the own Atersa, as well as makers of batteries specific for photovoltaic, normally of lead-acid, between which is the prestigious Tudor mark.

\section{Research and Development}

Research activities of the photovoltaic solar technology in Spain are made by the own companies of the sector as well as the research centres and universities. The research work of the firm Trama Tecnoambiental deserves special mention in the field of the isolated micro-grids, as much in the technological aspect as in the social one. As far as the research centres, it must be emphasized among others the Institute of Renewable Energies (Instituto de Energías Renovables - IER) of the Research Centre for Energy, Environment and Technology (Centro de Investigaciones Energéticas, Medioambientales y Tecnológicas, CIEMAT), with projects such as the optimization of PV modules for integration in buildings and studies of degradation of the modules; or the Institute of Solar Energy (Instituto de Energía Solar - IES) of the Polytechnic University of Madrid with investigations on bifacial cells and technology of thin layer.

Important projects of demonstration recently implemented are the PV Pergola of the Moncloa Palace in Madrid, seat of the Spanish Prime Minister, or the 1.2
MW PV grid-tie central in Tudela (Navarra) with solar trackers, that is going to have also an important research function.

\section{Conclusions}

The conclusions of the review of the solar photovoltaic energy in Spain can be summarized in:

- The objectives of photovoltaic implantation for the 2010 have been marked

- The legislative bases that regulate the administrative, technical and economic aspects of the electrical producers with renewable energies (photovoltaic) have settled down

- The development of the PV sector is being helped financially by means of multiannual plans, although this financing is turning out to be scarce to fulfil the objectives fixed

- A developed market exists enough that shows clear signs of maturity

- The photovoltaic industry in Spain occupies an important position at world-wide level and it is being developed of form maintained with great manufacturing projects on the way

- There exists a good number of installers and providers with an ample distribution by Spanish geography

\section{References}

[1] European Commission. "Energy for the Future: Renewable Sources of Energy. White Paper for a Community Strategy and Action Plan". COM(97) 599 of 26.11.1997.

[2] Greenpeace- European photovoltalic industry association. "Solar generation". 2001

[3] Plan de Fomento de las Energías Renovables para el período 2000-2010.1999

[4] IDAE. Eficiencia energética y energías renovables. October 2001 